\title{
The Relationship between the Perceived Mental Benefits, Online Trust, and Personal Information Disclosure in Online Shopping
}

\author{
Ha Minh NGUYEN ${ }^{1}$, Bui Thanh KHOA ${ }^{2}$
}

Received: July 27, 2019 Revised: September 16, 2019 Accepted: September 24, 2019

\begin{abstract}
The study examines the relationship between perceived mental benefits, online trust, and personal information disclosure when shopping online in Vietnam. The e-commerce market has been booming in Vietnam since 2015. The number of online transactions and e-commerce sites has increased steadily in recent years. However, the number of online sales in Vietnam is still not high, and consumers are still limited in buying from websites when they have to provide too much information during and after the shopping process. The mix-method is used to ensure the scientific nature of the study. Qualitative research method (phenomenological research) along with the quantitative research method (survey) are applied to meet the research objectives. The data in the study was collected through the group discussion with eight experts and the survey with 917 respondents. Data processing result via SmartPLS software indicate the positive relationships between the factors in the research. The perceived mental benefits have the most potent influence on the online trust of Vietnamese customers; at the same time, both the perceived mental benefits and online trust affect customers personal information disclosure in electronic commerce. Some managerial implications relating increasing the perceived mental benefits, and customers' online trust are proposed for online businesses.
\end{abstract}

Keywords : Perceived Mental Benefits, Online Trust, Personal Information Disclosure, Electronic Commerce

JEL Classification Code : M31, L81, L86

\section{Introduction}

The number of e-commerce sites continuously increased from 2013 to 2017, especially increasing rapidly since 2015. Vietnamese enterprises established e-commerce site reached 18,783 in 2017 (Vietnam eCommerce and Digital Economy Agency, 2018). Vietnam e-commerce market is a vibrant market with both the number of buyers and sellers increasing every year. That also increases the competition between online businesses, and the success of an online retailer in the e-commerce market in Vietnam is difficult to achieve.

1 First Author, Associate Professor, Ho Chi Minh City Open University, Vietnam. Email: ha.nm@ou.edu.vn

2 Corresponding Author, Lecturer, Ho Chi Minh City Open University, Vietnam. [Postal Address: 20 Street 8, Quarter 2, Hiep Binh Chanh Ward, Thu Duc District, Ho Chi Minh City, 700000, Vietnam] Email: khoabt.15ab@ou.edu.vn, khoadhcn@gmail.com

(c) Copyright: Korean Distribution Science Association (KODISA)

This is an Open Access article distributed under the terms of the Creative Commons Attribution Non-Commercial License (http://Creativecommons.org/licenses/by-nc/4.0/) which permits unrestricted noncommercial use, distribution, and reproduction in any medium, provided the original work is properly cited.
The success of e-commerce sites is determined through two parameters; that is, the number of visitors and the number of views per customer (Tarafdar \& Zhang, 2008). In order to accomplish the two goals above, businesses must take care of and maintain regular contact with customers. The personal information provided by customers is one of the essential factors that help businesses accomplish this task. In e-commerce transactions, transactions are only completed when the customer provides personal information such as name, address, phone number, and payment information in the first transaction. However, to maintain a long-term relationship cannot happen if the user does not provide information to build customer profiles such as credit card information for one-click purchasing, or preferences (Campbell, 2019). Information exchange is one of the interactions between the customer and business, is a fundamental characteristic of relationships (Kelley, 1979). However, customers are often concerned about providing information to businesses (McCroskey \& Richmond, 1977), especially in the online shopping environment due to concerns about privacy risks. Also, the attraction factors that 
an organization brings to customers have a significant impact on using an e-commerce site to shop (Campbell, Wells, \& Valacich, 2013).

Many studies have shown that two of the more efficient means of creating customer loyalty are customer satisfaction (Lee, Lee, \& Feick, 2001) and provide outstanding value from services and excellent product quality (Parasuraman \& Grewal, 2000). Turner and Gellman (2013) argue that perceived benefits related to awareness of positive outcomes are due to a specific action. Perceived benefits in ecommerce indicate what customers achieve from online shopping (Forsythe, Liu, Shannon, \& Gardner, 2006). Sheth (1983) proposed that the individual elements of traditional procurement can be widely understood as being affected by functional and non-functional benefits. Today, customers will be attracted by non-functional benefits such as shopping enjoyment (Forsythe et al., 2006), social interaction (Hennig-Thurau, Gwinner, \& Gremler, 2002), privacy when shopping (Bhatia, Breaux, Reidenberg, \& Norton, 2016), or perceived control (Huang, 2003). The studies of hedonic benefits and flow theory in the online environment have been increasingly popular recently.

Many empirical surveys and studies have examined the importance of intrinsic and extrinsic motivations in the nonmarketing section. However, very few studies have investigated consumer motivation in marketing. Teo, Lim, and Lai (1999) pointed out that consumer motivation is an essential predictor of consumers' intention to use the Internet. Consumer intrinsic dynamics are more prominently used to explain consumers' intention to online shopping (Shang, Chen, \& Shen, 2005), and more likely to avoid buying luxury goods (Truong \& McColl, 2011). Although researchers have emphasized the importance of intrinsic and extrinsic motivations for better predicting behavioral intent, the best method is still unknown in grasping intrinsic and extrinsic dynamics. It is surprising to see that current marketing researches (and other business practices) have focused too much on extrinsic factors; however, it is necessary to gather perspectives that integrate intrinsic motivation (Gilal, Zhang, Paul, \& Gilal, 2019). Therefore, empirical research is needed to investigate whether internal motivation is more influential in predicting different marketing results. Moreover, consumers' online trust is also proposed as the mediator between the benefits and the provision of personal information. Research in the social networking environment of Loiacono (2015) has shown the trust factor after being aware of the benefits that make it easy for users to provide information on the sites.

The rest is organized as follows: Section 2 presents the literature for each research variable, determines the relationship between the research variables to build the research model. The next section details the research methods and presents research results. Finally, discuss the results with future research orientation.

\section{Literature Review}

\subsection{Perceived Mental Benefit}

Perceived benefits related to awareness of positive outcomes are due to a specific action (Turner \& Gellman, 2013). In e-commerce, perceived benefits indicate what customers get from online shopping (Forsythe et al., 2006). The concept of "mental" is related to wisdom as interpreted with emotional activity or involved in the thinking process (Oxford, 2010). From which, we can conclude the perceived mental benefit, is the psychological and emotional value that individuals feel when shopping online, included perceived enjoyment, perceived social interaction, perceived discreet, and perceived control (Nguyen \& Khoa, 2019).

\subsubsection{Perceived Enjoyment}

Perceived enjoyment is defined as the level of pleasure and comfort beyond the results of performance (Venkatesh \& Davis, 2000). The benefit comes from new experiences (Forsythe et al., 2006). Based on this result, the author thinks that enjoyable shopping can be an essential structure in the study of online consumer behavior. In particular, shopping enjoyment can have a significant impact on customer attitudes and behaviors on the web and can increase customer intentions to return. Enjoyment in shopping is considered a non-functional motivation (Sheth, 1983).

\subsubsection{Perceived Social Interaction}

Butler, Sproull, Kiesler, and Kraut (2002) believe that one of the personal benefits consumers expect to receive from contributing to an online community is to establish social relationships with others. Since then, in addition to the motivation to seek common knowledge and learning, the motivation to facilitate social interaction plays a significant role in the virtual community or e-commerce. Zhang and Hiltz (2003) also argue that those who come to the virtual community are not only to seek information or knowledge and solve problems but also look forward to meeting other people and finding support and friendship. According to Scheinkman (2008), social interactions are sometimes called non-market interactions to emphasize the fact that the price mechanism does not regulate these interactions. The virtual world becomes an excellent medium for individuals to develop their learning and thinking.

\subsubsection{Perceived Discreet}

Estes, Orbke, Penn, Pensabene, Ray, Rios, and Troxel (2007) pointed out that many consumers are uncomfortable or embarrassed when buying certain products from a retailer. For example, sex products, products for women, birth control pills. Gupta, Bansal, and Bansal (2013) define discreet shopping, which means consumers buy what they need privately and those who else; no one knows what they buy. Wood (2017) believes that some convenient and 
practical solutions describe discreet shopping on the Internet for those who want to buy sensitive products, but they are afraid to go to a shop. Therefore, anonymity can be the most distinctive factor compared to online and traditional shopping.

\subsubsection{Perceived Control}

Perceived control is as relevant as a person's belief in the ability to influence their internal state, behavior, and the external environment (Wallston, Wallston, Smith, \& Dobbins, 1987). Perceived control concepts include selfefficacy (Bandura, 1997)) and perceived behavioral control (Ajzen, 1985). In online services using new technology, two factors of perceived control include the customization and personalization (Godek \& Yates, 2005). Companies have begun to use new communication technologies to implement individual-appropriate collaborative strategies that can be more beneficial by creating a fit between consumer preferences and products supplied from the company (Prahalad \& Ramaswamy, 2000). Perceived control is a significant contributor to mental and physical health as well as a strong predictor of life achievements (Ly, Wang, Bhanji, \& Delgado, 2019).

\subsection{Online Trust}

Trust as the specific belief in integrity, benevolence, and ability of a buyer with a seller (Gefen, Karahanna, \& Straub, 2003). In the case of e-commerce, integrity is the belief that online sellers respect the stated rules or keep the promise. Ability is a belief in the skills and capabilities of online businesses to provide the right quality products and services. Benevolence is the belief that online sales sites, wanting to earn legitimate profits, want to bring good things to customers. Ang, Dubelaar, and Lee (2001) proposed that three aspects of trust are essential to improve trust on the Internet. These three aspects are the ability of the online business to deliver promised products or services, an online merchant's benevolence to fix if the purchase does not meet the satisfaction of the customer and the presence of a privacy policy or statement of e-commerce pages.

Good personalization is also a condition for forming online trust (Briggs, Simpson, \& De Angeli, 2004). The benefits of controlling feelings can have a positive impact on consumer confidence; however, if collecting customer data can also create an adverse reaction to online customer confidence (Beldad, De Jong, \& Steehouder, 2010; Khoa \& Khanh, 2019). Research by Park, Amendah, Lee, and Hyun (2019) also shows that the perceived benefit will affect customer confidence in the payment system via mobile devices. Therefore, the research hypothesizes $\mathrm{H} 1$ is proposed:

H1: The perceived mental benefits have a positive effect on online trust in e-commerce

\subsection{Personal Information Disclosure}

The concept of personal information is pervasive and in most cases. However, in some cases, it may not be clear, and the answer will depend on the context and situation. Personal information or sensitive personal data can be anything used to identify an individual. Information collected about customers may include their name, address, phone number, bank details, and credit card numbers.

In the global age, where information technology cannot be controlled, the disclosed personal information becomes a severe problem. The customer tends to keep their information for their privacy and safety (Gracia \& Juliadi, 2019). Disclosure of personal information also creates risks and vulnerability to customers, due to the potential for a data breach, identity theft, unwanted personal data usage and anxiety, and general vulnerability. Therefore, consumers tend to show an adverse reaction to any data collection efforts and are not willing to share personal data (Palmatier \& Martin, 2019).

Mayer, Davis, and Schoorman (1995) state that trust in the transaction is parties' readiness to be unsafe to one another. The buy-side and sell-side must be more vulnerable to one another for the occurrence of relationship progression. Such readiness represents an act of trust. In location-based services, the customer will disclose their position by GPS service to get the discount from the shop (Xu, Luo, Carroll, $\&$ Rosson, 2011). Online trust has been found to affect a customer's willingness to provide personal information on the Internet (Campbell, 2019; Dinev \& Hart, 2006). Therefore, we propose the hypothesis $\mathrm{H} 2$ :

H2: Online trust has a positive effect on personal information disclosure in e-commerce

Individuals will disclose personal information when they have enough benefits. Many websites offer coupons and discounts and customized the buying process if the customer provides their personal information, and their reference (Hann, Hui, Lee, \& Png, 2002). The privacy calculus model points that the customer will judge on the risks and benefits induced by the information disclosure behavior (Dinev \& Hart, 2006), and they will provide more personal information if the perceived benefits are higher than the perceived costs of disclosure. Perceived benefits are positively associated with information disclosure when they take part in location-based social network services (Sun, Wang, Shen, \& Zhang, 2015). Hence, we can propose the Hypothesis H3:

H3: The perceived mental benefits have a positive effect on personal information disclosure in e-commerce 


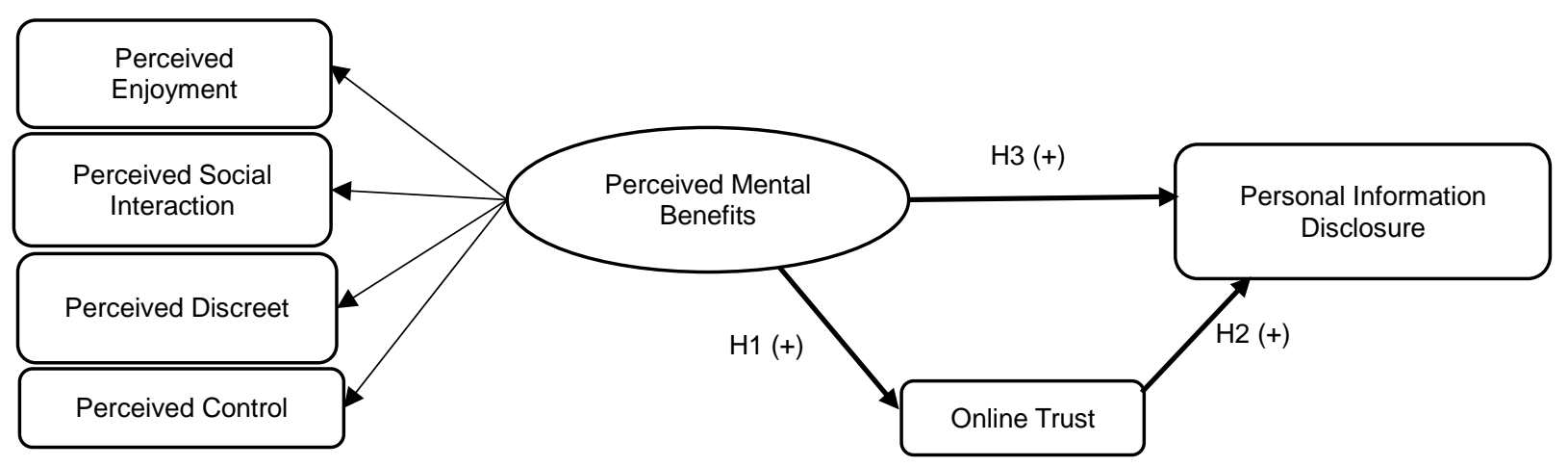

Figure 1: The theoretical model

\section{Methodology}

The mixed-method is used to achieve the research objectives set out. Phenomenological research is done to determine the factors as well as adjusting the questionnaire. Data is collected by focus group discussion (Rabiee, 2004; Silverman, 2004). Participants of the discussion included eight customers selected by the snowball method, having experience in e-commerce for over a year. The discussion took place under the presidency of the authors with a discussion guide. The results of qualitative research show that the mental benefit in shopping online encompass four factors (perceived enjoyment, perceived social interaction, perceived discreet, and perceived control); and most participants agree that they will disclose their personal information if they get the benefits from a website and trust the website. Besides, the scales in the study are also adjusted to suit the Vietnamese buyers, e-commerce context. The next step, the questionnaire is designed to be able to conduct quantitative research. Subjects surveyed by questionnaires focus on customer aged 18 to 45 , the job is the student, office worker, lecturer, civil servant, housewife, trader, worker because these are the people who need online shopping and have a good awareness of e-commerce (Department of E-Commerce and Information Technology, 2017). Since the study is in the field of e-commerce, it is recommended to use purpose-based sampling to select the survey respondents to understand the research problem and thereby expand the sample quickly (Neuman, 2002).

The scale of all research concepts in the paper adapted on the previous studies, adjusted through qualitative research, and presented in the form of a statement. The scale uses 5 points Likert scale from (1) Strongly disagree to (5) Strongly agree. Perceived mental benefits were taken as a second-order construct with four dimensions, namely perceived enjoyment, perceived social interaction, perceived discreet, and perceived control. They were measured using nineteen items from Nguyen and Khoa (2019). The online trust is measured with five items from Liu and Tang (2018). Personal information disclosure was measured with three items from Campbell (2019).
Table 1: Demographic profile

\begin{tabular}{|l|l|l|l|}
\hline \multicolumn{2}{|l|}{ Characteristics } & Frequency & $\%$ \\
\hline \multirow{4}{*}{ Gender } & Male & 458 & 49.9 \\
\cline { 2 - 4 } & Female & 459 & 50.1 \\
\hline \multirow{4}{*}{ Age } & 20 & 139 & 15.2 \\
\cline { 2 - 4 } & $20-24$ & 156 & 17.0 \\
\cline { 2 - 4 } & $25-29$ & 254 & 27.7 \\
\cline { 2 - 4 } & $30-34$ & 193 & 21.0 \\
\cline { 2 - 4 } & $>=35$ & 175 & 19.1 \\
\hline \multirow{4}{*}{ Occupation } & Student & 139 & 15.2 \\
\cline { 2 - 4 } & Lecturer & 107 & 11.7 \\
\cline { 2 - 4 } & Office worker & 246 & 26.8 \\
\cline { 2 - 4 } & Housewife & 99 & 10.8 \\
\cline { 2 - 4 } & Trader & 145 & 15.8 \\
\cline { 2 - 4 } & Civil servant & 152 & 16.6 \\
\cline { 2 - 4 } & Worker & 29 & 3.2 \\
\hline \multirow{4}{*}{ education } & High school graduate & 197 & 21.5 \\
\cline { 2 - 4 } & College graduate & 306 & 33.4 \\
\cline { 2 - 4 } & University graduate & 218 & 23.8 \\
\cline { 2 - 4 } & Master/PhD graduate & 196 & \\
\hline
\end{tabular}

950-panel members who were invited to participate in the study, 932 members responded, which represents a 98.11 percent response rate. After data cleaning, five responses were removed due to lack of information, selecting the answer that violates the reverse question. Total of 917 responses is used for further analysis by the SmartPLS software.

In particular, respondents did not have much difference in the proportion of men $(49.9 \%)$ and women $(50.1 \%)$. The occupation of participants are office worker $(26.8 \%)$, civil servant $(16.6 \%)$, trader $(15.8 \%)$ and student $(15.2 \%)$, this is a group of people who are often shopping online. The age of the respondents is in the range from below 20 to above 35, accounting for $80.9 \%$; and the level of education in College, University, and Master/Ph.D. is 720 people, accounting for $78.5 \%$. Thus, the research sample is suitable for research purposes (Table 1). 


\section{Results}

\subsection{Descriptive Statistic}

Table 2 shows the mean of all items in the research as well as the normal distribution of data. In general, the level of agreement with statements regarding perceived enjoyment, perceived control, and discreet shopping is moderate; the agreement mean of social interaction, online trust, and personal information disclosure are high. The skewness and kurtosis values of all variables that meet the normal distribution requirements (skewness less than 3, kurtosis is less than 10) (Kline, 2015).

Table 2: Descriptive Statistics

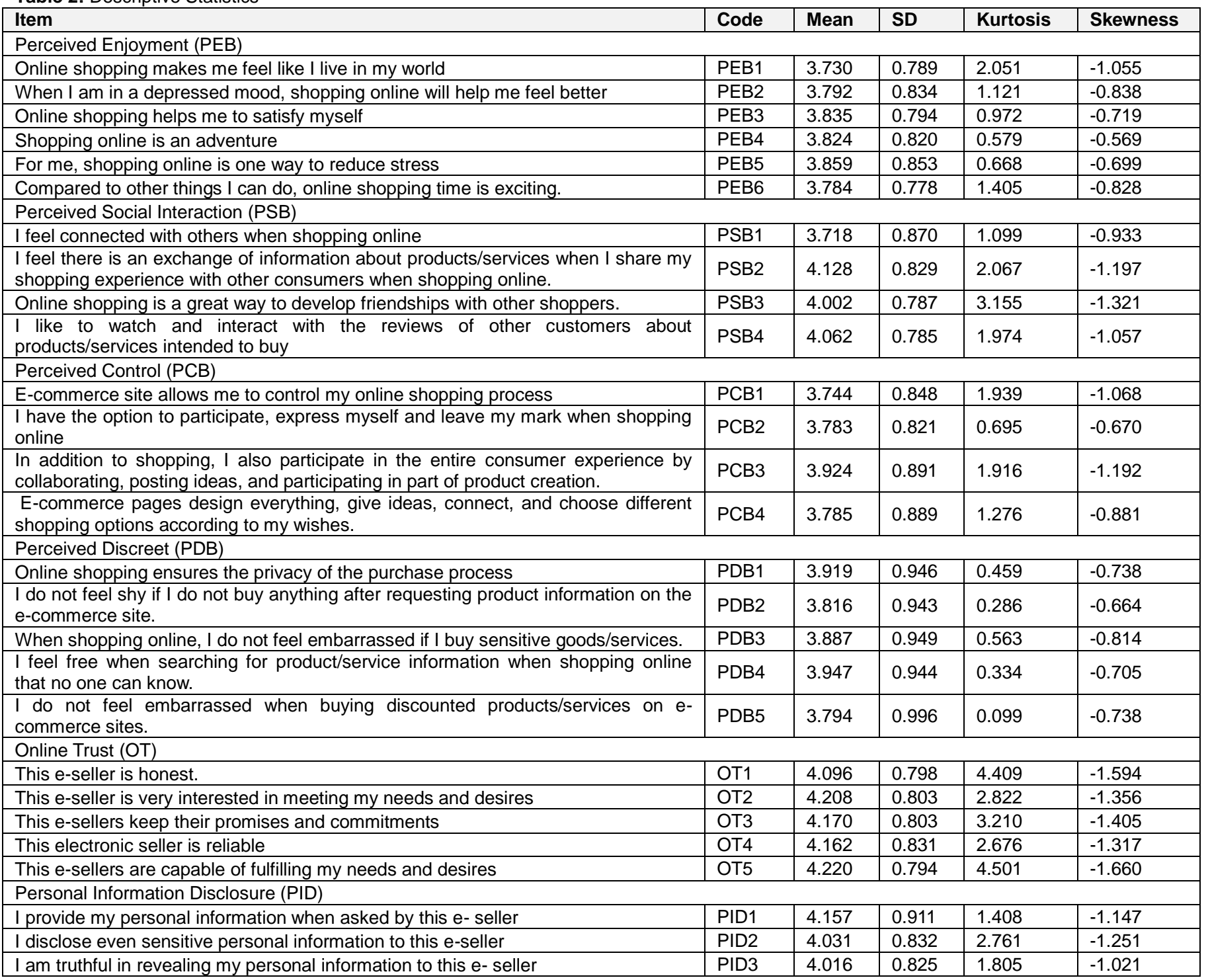

\subsection{Reliability and Validity Assessment}

According to Table 3, all scales are reliable; the confidence coefficient of 0.737 to 0.878 is higher than 0.70 (Nunnally \& Bernstein, 1994). 
Table 3: Results of outer loading, reliability, and validity

\begin{tabular}{|c|c|c|c|c|c|c|c|c|c|}
\hline Item & OT & PCB & PDB & PEB & PID & PSB & CA & CR & AVE \\
\hline OT3 & 0.833 & & & & & & \multirow[t]{2}{*}{0.878} & \multirow[t]{2}{*}{0.911} & \multirow[t]{2}{*}{0.673} \\
\hline OT5 & 0.773 & & & & & & & & \\
\hline PCB1 & & 0.835 & & & & & \multirow{2}{*}{0.869} & \multirow{2}{*}{0.910} & \multirow{2}{*}{0.717} \\
\hline PCB2 & & 0.846 & & & & & & & \\
\hline PDB1 & & & 0.923 & & & & \multirow{5}{*}{0.937} & \multirow{5}{*}{0.952} & \multirow{5}{*}{0.800} \\
\hline PDB2 & & & 0.901 & & & & & & \\
\hline PDB3 & & & 0.899 & & & & & & \\
\hline PDB4 & & & 0.892 & & & & & & \\
\hline PDB5 & & & 0.855 & & & & & & \\
\hline PEB1 & & & & 0.798 & & & \multirow{2}{*}{0.869} & \multirow{2}{*}{0.902} & \multirow{2}{*}{0.605} \\
\hline PEB6 & & & & 0.757 & & & & & \\
\hline PID1 & & & & & 0.804 & & \multirow{3}{*}{0.737} & \multirow{3}{*}{0.851} & \multirow{3}{*}{0.655} \\
\hline PID2 & & & & & 0.804 & & & & \\
\hline PID3 & & & & & 0.820 & & & & \\
\hline PSB1 & & & & & & 0.826 & \multirow{4}{*}{0.871} & \multirow{4}{*}{0.912} & \multirow{4}{*}{0.723} \\
\hline PSB2 & & & & & & 0.793 & & & \\
\hline PSB3 & & & & & & 0.916 & & & \\
\hline PSB4 & & & & & & 0.861 & & & \\
\hline
\end{tabular}

Note: CA: Cronbach's Alpha; CR: Composite Reliability; AVE: Average Variance Extracted

The reliability and discriminant of the scale checks by the Composite Reliability (CR) and the Average Variance Extracted (AVE). All scales meet the requirements (CR> 0.6, AVE> 0.5), reflecting the convergence of the structure (Fornell \& Larcker, 1981). Hence, all scales accomplish reliability and discriminant validity.

For this model, the research needs to estimate the relationship between the resulting potential variable and its observed variables, which confirm through the outer loadings. According to the results of Table 3, all external load indexes of PEB, PSB, PDB, PCB, OT, and PID concepts are higher than the allowable value of 0.708 (Hair, Hult, Ringle, \& Sarstedt, 2016). In particular, observed variable PEB5 has the lowest external load coefficient of 0.747 , and the observed variable PDB1 has the highest external load coefficient of 0.910 . Thus, the four potential variables are related to their observed variables.

The study of Hair et al. (2016) showed that HeterotraitMonotrait Ratio (HTMT) should be applied to detect discriminant validity reliably. Table 4 shows the value of HTMT for all pairs of variables in the study. It can be seen that all HTMT values are less than the thresholds of 0.85 (Hair, Hult, Ringle, \& Sarstedt, 2016). Therefore, all constructs in this research have discriminant validity.
Table 4: HTMT value for discriminant validity

\begin{tabular}{|l|l|l|l|l|l|l|}
\hline Construct & OT & PCB & PDB & PEB & PID & PSB \\
\hline OT & & & & & & \\
\hline PCB & 0.480 & & & & & \\
\hline PDB & 0.527 & 0.500 & & & & \\
\hline PEB & 0.722 & 0.493 & 0.443 & & & \\
\hline PID & 0.581 & 0.440 & 0.376 & 0.472 & & \\
\hline PSB & 0.697 & 0.392 & 0.417 & 0.583 & 0.506 & \\
\hline
\end{tabular}

\subsection{Assessment of PLS-SEM Structural Model Results}

The result of the assessment structural model for collinearity presents in Table 5. We assess the following sets of (predictor) constructs for collinearity: (1) PMB and OT as predictors of PID, (2) PMB as predictors of OT. All VIF values are less than the threshold of 5. Hence, the collinearity between predicted structures is not an essential issue in the structural model. 
Table 5: The result of the assessment structural model for collinearity

\begin{tabular}{|l|l|l|l|l|l|l|}
\hline & OT & PCB & PDB & PEB & PID & PSB \\
\hline OT & & & & & 2.054 & \\
\hline PMB & 1.000 & 1.000 & 1.000 & 1.000 & 2.054 & 1.000 \\
\hline
\end{tabular}

To start with, we examine the $R^{2}$ values of the endogenous latent variables, following the rules of thumb, the $\mathrm{R}^{2}$ values of OT $(0.513)$ considers moderate, whereas the $\mathrm{R}^{2}$ value of PID (0.262) is rather weak. $\mathrm{f}^{2}$ values for all combinations of endogenous constructs and corresponding exogenous constructs. In this research, PMB has a strong effect size of 1.054 on OT; PMB and OT have a weak effect size of 0.056 and 0.045 on PID. In addition to assessing the magnitude of $\mathrm{R}^{2}$ values as a criterion of predictive accuracy, Geisser (1974); Stone (1974) suggested checking the $\mathrm{Q}^{2}$ value, an indicator of predictive power beyond the model of the model or the level of predictability. In Table 6 , the $\mathrm{Q}^{2}$ values of all two endogenous constructs are considerably above zero; precisely, OT, and PID has moderate $\mathrm{Q}^{2}$ values (0.315 and 0.160).

Table 6: Result of $R^{2}, f^{2}, Q^{2}$

\begin{tabular}{|l|l|l|l|}
\hline & $\mathbf{R}^{2}$ & $\mathbf{f}^{2}$ & $\mathbf{Q}^{2}$ \\
\hline OT & 0.513 & 1.054 & 0.315 \\
\hline PID & 0.262 & $\begin{array}{l}0.045 / 0.056 \\
\text { (OT/PMB) }\end{array}$ & 0.160 \\
\hline
\end{tabular}

About the significance and relevance of the structural model relationships, the research use the Bootstrap procedure with 5000 random subsamples have been created (Hair et al., 2016). The results of Table 7 show that all the relationships in the structural model are significant with $\mathrm{p}$ value is less than 0.001 .

Table 7: The result of the structural model

\begin{tabular}{|l|l|l|l|l|l|}
\hline Relationship & $\mathbf{O}$ & $\mathbf{M}$ & STDEV & T Statistics & P Values \\
\hline OT -> PID & 0.260 & 0.261 & 0.060 & 4.366 & 0.000 \\
\hline PMB $->$ OT & 0.716 & 0.715 & 0.030 & 23.653 & 0.000 \\
\hline PMB - PID & 0.293 & 0.290 & 0.055 & 5.272 & 0.000 \\
\hline PMB $->$ PCB & 0.705 & 0.704 & 0.033 & 21.458 & 0.000 \\
\hline PMB -> PDB & 0.768 & 0.767 & 0.020 & 38.174 & 0.000 \\
\hline PMB -> PEB & 0.802 & 0.801 & 0.021 & 39.076 & 0.000 \\
\hline PMB -> PSB & 0.722 & 0.721 & 0.026 & 28.021 & 0.000 \\
\hline
\end{tabular}

Note: Original Sample (O); Sample Mean (M); Standard Deviation (STDEV)

\section{Discussion and Implication}

\subsection{Discussion}

The findings of this study complement the knowledge of the relationship between the perceived mental benefits, online trust, personal information disclosure, and anxiety of customer. First, as to the mental benefit structure, this research finds that in the Vietnam e-commerce context, which is regarded as four dimensions as perceived enjoyment, perceived social interaction, perceived discreet, and perceived control. This finding is suitable with the psychological theories as hedonic consumption (Hirschman \& Holbrook, 1982), flow theory (Csikszentmihalyi, 2008; Hoffman \& Novak, 1996), and self-determination theory (Deci \& Ryan, 1985; Sheth, 1981). Second, there is a positive impact of the perceived mental benefits and online trust on the personal information disclosure, and the perceived mental benefits have a positive effect on online trust. The hypothesis H1 is accepted that the perceived mental benefits have a positive relationship with online trust when purchasing in e-commerce $(\beta=0.716 ; \mathrm{p}<0.001)$. The statistical result also supports the hypothesis $\mathrm{H} 2$, which is the online trust that has a positive effect on customers' information disclosure $(\beta=0.260 ; p<0.001)$. The study results also confirmed the hypothesis $\mathrm{H} 3$; it means the perceived mental benefits positively impacted the personal information disclosure $(\beta=0.293 ; \mathrm{p}<0.001)$. The research result is adapted o relationship marketing framework not only in the traditional environment (Palmatier, Dant, Grewal, \& Evans, 2006) but also in the online environment (Verma, Sharma, \& Sheth, 2016).

\subsection{Implication}

In order to increase the perceived enjoyment for customers, businesses can provide more entertainment or useful services for their online shopping activities. Business can consider improving the real relationship between customers together through social channels, forums, or directly through the site or "Reviews \& comment" section. Many e-commerce sites do not have a comment section for each product on the e-commerce site. Also, the reward policy through comments is a policy that can be considered. Customers can choose the option to keep product information confidential during the distribution step. In other words, the goods will be packaged and enclosed with little information but enough to transport. Therefore, when receiving the package, customers will not be embarrassed or worried about other people knowing what they buy. Also, businesses must disclose their privacy policy on their ecommerce site to ensure their privacy. Electronic retailers should apply customization in business by giving customers more space to participate in the design of their products. Build a system for analyzing customer activities to understand their interests, concerns, or needs, or can link to 
third parties for more information about customer behavior.

Business needs to have many images and describe the functions and uses of the product. Besides, the business should provide additional evidence from reliable sources so that customers can evaluate when choosing or deciding to buy products. E-tailer needs to provide a return policy and a product exchange process on its e-commerce, and there should be a specialized department that accepts the processing and returning the payment to customers. Repayment to customers must be carried out in a simple process, and full customer support (recall, test, change of new products). Use reputable third parties to ensure peace of mind for customers when trading on the site and providing business information.

\section{Conclusions}

With a mixed research approach (including group interviews with eight experts, and a survey of 917 respondents), this study has shown the impact of perceived mental benefits and online trust on the customers' information disclosure in online transactions in a developing country in Asia, specifically Vietnam. In this relationship, the benefits create a significant impact on consumer's online trust, but both of these factors have a positive impact on the intention to provide personal information.

Although many efforts have been made, this study is also inevitable. First, e-commerce is a relatively wide field with many types, such as mobile commerce, social commerce. Research focusing on a specific area will create more profound and more accurate insights. Secondly, the method of sampling in the current study is using the non-probability method, which makes the results of the study less reliable. Future studies may use probability sampling methods to increase research reliability. Finally, the disclosure of personal information is an appropriate structure for new research directions. However, subsequent studies can expand output factors such as online loyalty, participation.

\section{References}

Ajzen, I. (1985). From intentions to actions: A theory of planned behavior. In J. Kuhl \& J. Beckmann (eds), Action control. SSSP Springer series in social psychology. Berlin, Germany: Springer. https://doi.org/10.1007/978-3-642-69746-3_2

Ang, L., Dubelaar, C., \& Lee, B.-C. (2001).To trust or not to trust? A model of internet trust from the customer's point of view. Proceedings of the 14th Bled Electronic Commerce Conference (pp. 40-52), Bled, Slovenia. Retrieved from https://aisel.aisnet.org/bled2001/43/

Bandura, A. (1997). Self-efficacy: The exercise of control. New York, NY: W.H. Freeman and Company.
Beldad, A., De Jong, M., \& Steehouder, M. (2010). How shall I trust the faceless and the intangible? A literature review on the antecedents of online trust. Computers in Human Behavior, 26(5), 857-869. https://doi.org/10.1016/j.chb.2010.03.013

Bhatia, J., Breaux, T. D., Reidenberg, J. R., \& Norton, T. B. (2016). A theory of vagueness and privacy risk perception. Paper presented at the 2016 IEEE 24th International Requirements Engineering Conference (RE). https://doi.org/10.1109/re.2016.20

Briggs, P., Simpson, B., \& De Angeli, A. (2004). Personalisation and trust: A reciprocal relationship? In C. M. Karat, J. O. Blom, \& J. Karat (eds), Designing personalized user experiences in eCommerce. HumanComputer Interaction Series (vol 5, pp. 39-55). Dordrecht, Germany: Springer.

Butler, B., Sproull, L., Kiesler, S., \& Kraut, R. (2002). Community effort in online groups: Who does the work and why. Leadership at a Distance: Research in Technologically Supported Work, 1, 171-194.

Campbell, D. E. (2019). A relational build-up model of consumer intention to self-disclose personal information in E-commerce B2C relationships. AIS Transactions on Human-Computer Interaction, 11(1), 33-53. https://doi.org/10.17705/1thci.00112

Campbell, D. E., Wells, J. D., \& Valacich, J. S. (2013). Breaking the ice in $\mathrm{B} 2 \mathrm{C}$ relationships: Understanding pre-adoption e-commerce attraction. Information Systems Research, 24(2), 219-238.

Csikszentmihalyi, M. (2008). Flow: The psychology of optimal experience. New York, NY: Harper Perennial Modern Classics.

Deci, E., \& Ryan, R. M. (1985). Intrinsic motivation and self-determination in human behavior. Heidelberg, Germany: Springer Science \& Business Media. https://doi.org/10.1007/978-1-4899-2271-7

Department of E-Commerce and Information Technology. (2017). Vietnam E-Commerce report 2017. Retrieved July $12, \quad 2019, \quad$ from http://www.idea.gov.vn/file/335ad166-71c3-48dc-9bf8f1b13323843a

Dinev, T., \& Hart, P. (2006). An extended privacy calculus model for e-commerce transactions. Information Systems Research, 17(1), 61-80. https://doi.org/10.1287/isre.1060.0080

Estes, J., Orbke, W. H., Penn, M. C., Pensabene, P. A., Ray, C. R., Rios, J. F., \& Troxel, K. J. (2007). U.S. Patent No. 7,295,997. Washington, DC: U.S. Patent and Trademark Office.

Fornell, C., \& Larcker, D. F. (1981). Evaluating structural equation models with unobservable variables and measurement error. Journal of Marketing Research, 18(1), 39-50. https://doi.org/10.2307/3150979

Forsythe, S., Liu, C., Shannon, D., \& Gardner, L. C. (2006). Development of a scale to measure the perceived benefits and risks of online shopping. Journal of 
Interactive $\quad$ Marketing, 20(2), 55-75. https://doi.org/10.1002/dir.20061

Gefen, D., Karahanna, E., \& Straub, D. W. (2003). Trust and TAM in online shopping: An integrated model. MIS Quarterly, 27(1), 51-90.

Gilal, F. G., Zhang, J., Paul, J., \& Gilal, N. G. (2019). The role of self-determination theory in marketing science: An integrative review and agenda for research. European Management Journal, 37(1), 29-44. https://doi.org/10.1016/j.emj.2018.10.004

Godek, J., \& Yates, J. F. (2005). Marketing to individual consumers online: The influence of perceived control. In C. P. Haugtvedt, K. A. Machleit, \& R. Yalch (eds.), Online consumer psychology: Understanding and influencing consumer behavior in the virtual world (pp. 225-244). London, UK: Psychology Press.

Gracia, E., \& Juliadi, R. (2019). The threat of personal information trading in the online network and information technology. International Journal of Multicultural and Multireligious Understanding, 6(9), 49-55.

Gupta, A., Bansal, R., \& Bansal, A. (2013). Online shopping: A shining future. International Journal of TechnoManagement Research, 1(1), 1-10.

Hair, J. F., Hult, G. T. M., Ringle, C., \& Sarstedt, M. (2016). A primer on partial least squares structural equation modeling (PLS-SEM). Thousand Oaks, CA: Sage.

Hann, I.-H., Hui, K.-L., Lee, T., \& Png, I. (2002). Online information privacy: Measuring the cost-benefit trade-off. Proceedings of The International Conference on Information Systems (pp.1 - 10). December 15-18, 2002, Barcelona, Spain.

Hennig-Thurau, T., Gwinner, K. P., \& Gremler, D. D. (2002). Understanding relationship marketing outcomes: An integration of relational benefits and relationship quality. Journal of Service Research, 4(3), 230-247.

Hirschman, E. C., \& Holbrook, M. B. (1982). Hedonic consumption: Emerging concepts, methods and propositions. Journal of Marketing, 46(3), 92-101. https://doi.org/10.2307/1251707

Hoffman, D. L., \& Novak, T. P. (1996). Marketing in hypermedia computer-mediated environments: Conceptual foundations. Journal of Marketing, 60(3), 50-68. https://doi.org/10.1177/002224299606000304

Huang, M.-H. (2003). Designing website attributes to induce experiential encounters. Computers in Human Behavior, 19(4), 425-442. https://doi.org/10.1016/s07475632(02)00080-8

Kelley, H. H. (1979). Personal relationships: Their structures and processes. Hillsdale, NJ: Erlbaum.

Khoa, B. T., \& Khanh, T. (2019). Studying factors affecting online trust of the Vietnamese customers: Social commerce case. Vietnam Trade and Industry Review, 5, $198-205$.

Kline, R. B. (2015). Principles and practice of structural equation modeling. New York, NY: Guilford publications.
Lee, J., Lee, J., \& Feick, L. (2001). The impact of switching costs on the customer satisfaction-loyalty link: Mobile phone service in France. Journal of Services Marketing, $15(1)$, $35-48$. https://doi.org/10.1108/08876040110381463

Liu, Y., \& Tang, X. (2018). The effects of online trustbuilding mechanisms on trust and repurchase intentions. Information Technology \& People, 31(3), 666-687. https://doi.org/10.1108/itp-10-2016-0242

Loiacono, E. T. (2015). Self-disclosure behavior on social networking web sites. International Journal of Electronic Commerce, 19(2), 66-94. https://doi.org/10.2224/sbp.2015.43.1.1

Ly, V., Wang, K. S., Bhanji, J., \& Delgado, M. R. (2019). A reward-based framework of perceived control. Frontiers in Neuroscience, 13 https://doi.org/10.3389/fnins.2019.00065

Mayer, R. C., Davis, J. H., \& Schoorman, F. D. (1995). An integrative model of organizational trust. Academy of Management Review, 20(3), 709-734. https://doi.org/10.5465/amr.1995.9508080335

McCroskey, J. C., \& Richmond, V. P. (1977). Communication apprehension as a predictor of selfdisclosure. Communication Quarterly, 25(4), 40-43. https://doi.org/10.1080/01463377709369271

Neuman, L. W. (2002). Social research methods: Qualitative and quantitative approaches. Boston, MA: Allyn \& Bacon.

Nguyen, M. H., \& Khoa, B. T. (2019). Perceived mental benefits of online shopping. Journal of Science, 14(1), 3 17.

Nunnally, J. C., \& Bernstein, I. (1994). The assessment of reliability. Psychometric Theory, 3(1), 248-292.

Palmatier, R. W., Dant, R. P., Grewal, D., \& Evans, K. R. (2006). Factors influencing the effectiveness of relationship marketing: A meta-analysis. Journal of Marketing, 70(4), 136-153. https://doi.org/10.1509/jmkg.70.4.136

Palmatier, R. W., \& Martin, K. D. (2019). Understanding and valuing customer data. In R. W. Palmatier \& K. D. Martin (eds), The intelligent marketer's guide to data privacy: The impact of big data on customer trust (pp. 133-151). London, England: Palgrave Macmillan.

Parasuraman, A., \& Grewal, D. (2000). The impact of technology on the quality-value-loyalty chain: A research agenda. Journal of the Academy of Marketing Science, 28(1), 168-174. https://doi.org/10.1177/0092070300281015

Park, J., Amendah, E., Lee, Y., \& Hyun, H. (2019). Mpayment service: Interplay of perceived risk, benefit, and trust in service adoption. Human Factors and Ergonomics in Manufacturing \& Service Industries, 29(1), 31-43. https://doi.org/10.1002/hfm.20750

Prahalad, C. K., \& Ramaswamy, V. (2000). Co-opting customer competence. Harvard Business Review, 78(1), 79-90. 
Rabiee, F. (2004). Focus-group interview and data analysis. Proceedings of the Nutrition Society, 63(04), 655-660. https://doi.org/10.1079/pns2004399

Scheinkman, J. A. (2008). The new palgrave dictionary of economics (2 ed.). New York, NY: Palgrave Macmillan.

Shang, R.-A., Chen, Y.-C., \& Shen, L. (2005). Extrinsic versus intrinsic motivations for consumers to shop online. Information \& Management, 42(3), 401-413. https://doi.org/10.1016/j.im.2004.01.009

Sheth, J. N. (1983). An integrative theory of patronage preference and behavior. In W. F. Darden \& R. F. Lusch (eds), Patronage behavior and retail management (pp.928.). New York, NY: North-Holland.

Silverman, D. (ed.). (2004). Qualitative research: Theory, method and practice. Thousand Oaks, CA: Sage.

Sun, Y., Wang, N., Shen, X.-L., \& Zhang, J. X. (2015). Location information disclosure in location-based social network services: Privacy calculus, benefit structure, and gender differences. Computers in Human Behavior, 52, 278-292. https://doi.org/10.1016/j.chb.2015.06.006

Tarafdar, M., \& Zhang, J. (2008). Determinants of reach and loyalty: Study of website performance and implications for website design. Journal of Computer Information Systems, 48(2), 16-24.

Teo, T. S., Lim, V. K., \& Lai, R. Y. (1999). Intrinsic and extrinsic motivation in Internet usage. Omega, 27(1), 2537. https://doi.org/10.1016/s0305-0483(98)00028-0

Truong, Y., \& McColl, R. (2011). Intrinsic motivations, self-esteem, and luxury goods consumption. Journal of Retailing and Consumer Services, 18(6), 555-561. https://doi.org/10.1016/j.jretconser.2011.08.004
Turner, J. R., \& Gellman, M. (2013). Encyclopedia of behavioral medicine. New York, NY: Springer.

Venkatesh, V., \& Davis, F. D. (2000). A theoretical extension of the technology acceptance model: Four longitudinal field studies. Management Science, 46(2), 186-204. https://doi.org/10.1287/mnsc.46.2.186.11926

Verma, V., Sharma, D., \& Sheth, J. (2016). Does relationship marketing matter in online retailing? A meta-analytic approach. Journal of the Academy of Marketing Science, 44(2), 206-217. https://doi.org/10.1007/s11747-015-0429-6

Vietnam eCommerce and Digital Economy Agency. (2018). Vietnam E-Commerce white paper 2018. Retrieved July 30, 2019 from http://www.idea.gov.vn/file/c08520aa0222-4c61-af72-12e0477151b6

Wallston, K. A., Wallston, B. S., Smith, S., \& Dobbins, C. J. (1987). Perceived control and health. Current Psychology, 6(1), 5-25. https://doi.org/10.1007/bf02686633

Wood, R. (2017). Consumer sexualities: Women and sex shopping. London: Routledge.

Xu, H., Luo, X. R., Carroll, J. M., \& Rosson, M. B. (2011). The personalization privacy paradox: An exploratory study of decision-making process for location-aware marketing. Decision Support Systems, 51(1), 42-52. https://doi.org/10.1016/j.dss.2010.11.017

Zhang, Y., \& Hiltz, S. R. (2003). Factors that influence online relationship development in a knowledge-sharing community. Proceedings of the Ninth American Conference on Information Systems (pp. 410-417). August 4-6, 2003, Tampa, FL, USA. 